\title{
Pengurangan Yellow Reject pada Proses Hexavalent Chrome Plating on Plastic dengan Menggunakan Pendekatan DMAIC
}

\author{
M. Yani Syafei ${ }^{1}$, Sophia Louren ${ }^{2}$ \\ ${ }^{1,2}$ Faculty of Engineering, Industrial Engineering Department, President University \\ Jl. Ki Hajar Dewantara \\ Kota Jababeka,Cikarang, Bekasi - Indonesia 17550 \\ Email: ${ }^{1}$ yanisyafei@president.ac.id, ${ }^{2}$ slouren45@gmail.com
}

\begin{abstract}
Product quality is one of the important aspects for the company because it involves the existence, performance, productivity and profit of the company. Quality is obtained by having quality control to minimize products and produce products according to specifications. PT. Mitra Part Perkasa as a company that provides a service of chrome plating on plastics. The company is having a new quality issue of new reject that happened on hexavalent chrome process, namely yellow reject during September and October 2019 which had never happened before. The percentage of yellow rejects that happened was more than company tolerant limits of $1.5 \%$. To overcome this problem, using DMAIC is applied to reduce the number of rejects. The first step of DMAIC is the goal of the problem and agreed upon research objectives. The second step is to measure current quality with a control chart and decide yellow rejects as the main focus of research using pareto diagram. The third step is to analyze the yellow root causes using why why analysis and fishbone diagram. The fourth step is improvement based on each factor, man, material, method, and machine. The last step is control, this step will show the results of the improvements indicated by before the repairs were made. Based on the results, the percentage of yellow reject decreased from $2.77 \%$ to $0.55 \%$ and it can be concluded that DMAIC has succeeded in reducing yellow rejects.
\end{abstract}

Keywords: Chrome Plating on Plastic, Hexavalent Chrome Process, Yellow Reject, DMAIC, SIPOC Diagram, Control Chart, Diagram Pareto, Why Why Analysis, Fishbone Diagram.

\begin{abstract}
ABSTRAK
Kualitas produk adalah salah satu aspek penting bagi perusahaan karena menyangkut eksistensi, kinerja, produktivitas dan profit perusahaan. Kualitas yang baik diperoleh dengan adanya kontrol kualitas untuk meminimalisasi cacat produk dan menghasilkan produk yang sesuai spesifikasi. PT. Mitra Part Perkasa merupakan perusahaan yang bergerak dalam industri jasa chrome plating on plastic. Perusahaan mengalami masalah terkait masalah kualitas, dengan munculnya jenis reject baru pada proses hexavalent chrome, yaitu yellow reject selama bulan September dan Oktober 2019 yang sebelumnya belum pernah terjadi. Persentase yellow reject yang terjadi pun telah melebihi persentase reject yang diizinkan yaitu 1.5\%. Untuk mengatasi masalah tersebut, pendekatan DMAIC diterapkan untuk mengurangi jumlah reject. Langkah pertama DMAIC adalah mendefinisikan masalah dan menetapkan tujuan penelitian. Langkah kedua adalah mengukur kualitas kondisi saat ini dengan control chart dan memutuskan yellow reject sebagai fokus utama penelitian dengan menggunakan diagram pareto. Langkah ketiga adalah menganalisis akar penyebab yellow reject menggunakan why why analysis dan fishbone diagram. Langkah keempat adalah melakukan perbaikan berdasarkan setiap akar penyebab masalah dengan faktor man, material, method, dan machine. Langkah terakhir adalah kontrol, langkah ini akan menunjukkan hasil perbaikan serta perbandingan dengan sebelum perbaikan dilakukan. Berdasarkan hasil, persentase yellow reject terjadi penurunan dari $2.77 \%$ menjadi $0.55 \%$, dan dapat disimpulkan bahwa pendekatan DMAIC telah berhasil mengurangi jumlah yellow reject.
\end{abstract}

Kata Kunci: Chrome Plating on Plastic, Proses Hexavalent Chrome, Yellow Reject, Pendekatan DMAIC, SIPOC Diagram, Control Chart, Diagram Pareto, Why Why Analysis, Fishbone Diagram.

\section{Pendahuluan}

Saat ini yang menjadi persaingan ketat antar perusahaan adalah masalah kualitas. Kualitas merupakan adanya kesesuaian dengan persyaratan ataupun spesifikasi (Crosby, 1979). Kualitas produk harus diperhatikan dengan baik, karena ketika kualitas produk tersebut buruk akan mempengaruhi nama perusahaan atau merk itu sendiri, dan terlebih lagi kompetitor dapat menguasai dan mengambil alih pasar. Permasalahan kualitas adalah salah satu strategi perusahaan agar memiliki daya saing dan mampu mempertahankan eksistensinya 
terhadap persaingan global, karena tidak semua perusahaan memiliki dan mampu mencapai kualitas superior (Kotler dan Armstrong, 2008). Hal ini menyebabkan perusahaan harus bisa mempertahankan kualitas produk yang dihasilkannya atau bahkan lebih baik lagi (La Hatani, 2007). Oleh karena itu, perusahaan harus memperhatikan kualitas setiap proses produksi agar terhindar dari kegagalan produksi yang menyebabkan produk cacat.

Pendekatan DMAIC merupakan sebuah metode yang diketahui dapat menyelesaikan permasalahan kualitas dan perbaikan proses dengan melakukan perbaikan berkesinambungan (continuous improvement) untuk menurunkan tingkat produk cacat, sehingga menghasilkan kualitas yang baik dan memberikan dampak positif bagi perusahaan (Evans dan Lindsay, 2005).

Perusahaan yang menjadi objek penelitian merupakan suatu perusahaan manufaktur yang bergerak dalam bidang Chrome Plating on Plastic (POP). Perusahaan ini memiliki permasalahan dengan adanya jenis cacat yang baru hingga menimbulkan reject baru yang belum pernah ada pada bulan-bulan sebelumnya, yaitu yellow reject pada bulan September-Oktober 2019 dengan persentase reject yang tinggi. Hal tersebut berdampak pada penurunan kualitas, penurunan produktivitas, dan penurunan profit perusahaan. Batas toleran yang ditetapkan perusahaan untuk barang reject terhadap jumlah produksi keseluruhan adalah sebesar $3 \%$, dan untuk setiap jenis reject sebesar $1.5 \%$.

Yellow reject yang terjadi selama bulan September-Oktober 2019 bisa dikatakan cukup tinggi dan berada di luar batas toleran reject perusahaan. Yellow reject tersebut diidentifikasi terjadi pada proses hexavalent chrome, oleh karena itu penelitian difokuskan pada proses tersebut. Karena permasalahan tersebut tergolong baru, perusahaan belum menganalisis faktor-faktor apa saja yang memungkinkan yellow reject terjadi maupun ide-ide serta tindakan yang akan diambil sebagai solusi perbaikan dan mencegah agar permasalahan ini tidak terulang kembali, maka diperlukan baik informasi, data, serta metode untuk mengatasi hal tersebut.

\section{Metodologi Penelitian}

Metode yang digunakan pada penelitian ini adalah DMAIC, yaitu kepanjangan dari Define, Measure, Analyze, Improve, dan Control. DMAIC merupakan suatu strategi yang dapat diimplementasikan sebagai prosedur keberhasilan dalam peningkatan kualitas, peningkatan proses, dan mengurangi tingkat cacat (defect rate) (Pande dan Holpp, 2005). Kelima tahap tersebut diuraikan sebagai berikut :

\section{Define}

Define merupakan langkah operasional pertama dalam program peningkatan kualitas dengan metode DMAIC. Tahap ini bertujuan untuk menentukan atau mengidentifikasi permasalahan dan berfungsi untuk menentukan sasaran kegiatan yang akan dilakukan tindakan perbaikan (improvement) serta elemen-elemen yang mempengaruhi produksi dengan SIPOC diagram (Pyzdek dan Keller, 2010).

\section{Measure}

Tahap measure melibatkan pengumpulan data yang relevan dengan penelitian. Data tersebut dapat dikumpulkan berdasarkan data historis dan observasi secara langsung dilapangan ataupun melalui berbagai cara lain. Tujuan dari tahap ini adalah untuk mengevaluasi dan mengidentifikasi kondisi proses saat ini (Evans dan Lindsay, 2005). Pada tahap ini dilakukan pengolahan data dari data yang sudah terkumpul untuk pembuatan peta kendali $\mathrm{p}$ ( -chart) untuk mengetahui apakah proses terkendali baik dari sisi proporsi produk cacat, menghitung persentase reject dengan pembuatan diagram pareto, menghitung DPMO (Defect Per Million Opportunities) dan level sigma.

\section{Analyze}

Tahap analyze mulai memasuki ke proses dan hal-hal yang lebih detail dengan menentukan dan mengidentifikasi akar penyebab dan hubungan sebab akibat dari suatu permasalahan yang dapat di analisis dengan menggunakan why why analysis dan fishbone diagram (Evans dan Lindsay, 2005).

\section{Improve}

Pada tahap improve diuraikan ide-ide perbaikan atau solusi perbaikan sesuai hasil identifikasi dari penyebab kegagalan yang telah teridentifikasi sebelumnya untuk menurunkan tingkat reject, yang kemudian diimplementasikan sebagai bentuk perbaikan dari permasalahan tersebut. 
5. Control

Control merupakan tahap terakhir dalam pendekatan DMAIC. Pada tahap ini diperlukan adanya pengawasan atau evaluasi secara rutin dalam rangka pencapaian dan pemeliharaan kinerja untuk mengetahui performansi dari hasil perbaikan tersebut. Tahap ini pun yang berfungsi untuk mengendalikan, memantau, dan menjaga proses yang telah dilakukan melalui langkah-langkah diatas agar tetap terkendali (Evans dan Lindsay, 2005). Pada tahap ini dilakukan pengolahan data setelah perbaikan untuk membuat p-chart setelah perbaikan, menghitung DPMO dan level sigma, serta membandingkan hasil sebelum dan sesudah dilakukannya perbaikan.

\section{Hasil dan Pembahasan}

\subsection{Define}

\subsubsection{Identifikasi Masalah}

Masalah yang sedang dihadapi oleh perusahaan chrome plating akhir-akhir ini selama bulan SeptemberOktober 2019 adalah adanya permasalahan baru yaitu banyaknya reject produk plating plastik yang terjadi pada proses hexavalent chrome terutama jenis yellow reject yang sebelumnya belum pernah terjadi, sehingga penelitian pun dibatasi hanya pada proses hexavalent chrome. Data reject terhadap total produksi disajikan dalam Tabel 1 sebagai berikut.

Tabel 1. Data Jumlah Reject pada Proses Hexavalent Chrome Periode September-Oktober 2019

\begin{tabular}{|c|c|c|c|c|c|c|c|c|}
\hline \multirow{2}{*}{ No } & \multirow{2}{*}{ Bulan } & \multirow{2}{*}{$\begin{array}{c}\text { Jumlah } \\
\text { Produksi }\end{array}$} & \multirow{2}{*}{$\begin{array}{l}\text { Jumlah } \\
\text { Reject }\end{array}$} & \multicolumn{4}{|c|}{ Jenis Reject } & \multirow{2}{*}{$\begin{array}{c}\text { Persentase } \\
\text { Reject }\end{array}$} \\
\hline & & & & $\begin{array}{c}\text { Burn } \\
\text { Chrome }\end{array}$ & Yellow & Cloudy & Bintik & \\
\hline 1 & September & 70,859 & 3,309 & 578 & 1,855 & 509 & 367 & $4.67 \%$ \\
\hline 2 & Oktober & 75,678 & 3,603 & 634 & 2,198 & 473 & 298 & $4.76 \%$ \\
\hline & Total & 146,537 & 6,912 & 1,212 & 4,053 & 982 & 665 & $\begin{array}{c}\text { Rata-rata }= \\
4.72 \%\end{array}$ \\
\hline \multicolumn{4}{|c|}{$\begin{array}{c}\text { Persentase reject setiap jenis } \\
\text { cacat }\end{array}$} & $0.83 \%$ & $2.77 \%$ & $0.67 \%$ & $0.45 \%$ & \\
\hline
\end{tabular}

Dari data yang diperoleh dalam tabel tersebut menunjukkan bahwa adanya fluktuasi pada jumlah reject setiap bulannya. Adapun persentase reject jenis cacat paling besar yaitu yellow sebesar $2.77 \%$, diikuti burn chrome sebesar $0.83 \%$, cloudy sebesar $0.67 \%$, dan bintik sebesar $0.45 \%$.

\subsubsection{SIPOC Diagram}

Diagram SIPOC digunakan untuk melihat secara sekilas tentang aliran kerja suatu proses produksi, mengidentifikasi dan menunjukkan korelasi serta interaksi antara seluruh proses atau kegiatan (Juran, 1989). SIPOC diagram proses produksi chrome plating ditunjukkan pada Gambar 1 berikut. 

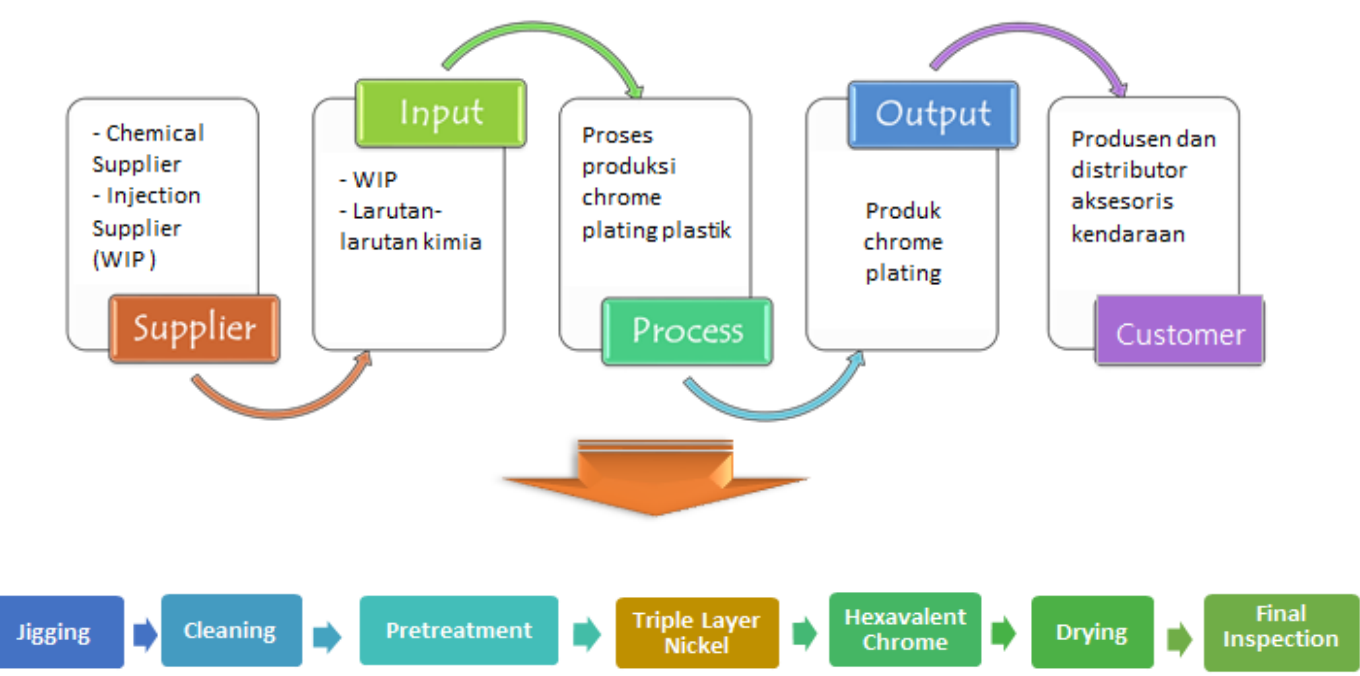

Gambar 1. SIPOC Diagram

\subsection{Measure}

\subsubsection{P-Chart}

Pengukuran yang sering dipakai untuk mengetahui kondisi suatu proses yaitu salah satunya dengan menggunakan peta kendali. Penelitian ini menggunakan peta kendali $p$ ( $p$-chart) untuk mengukur proporsi reject. P-chart digunakan untuk menunjukkan dan menggambarkan apakah suatu proses masih dalam batas kendali atau diluar batas kendali (out of control) (Antony, 2011). Sampel yang digunakan untuk pengukuran dalam penelitian bervariasi atau tidak konstan yang diambil setiap hari selama bulan September-Oktober 2019. Grafik hasil p-chart ditunjukkan pada Gambar 2.

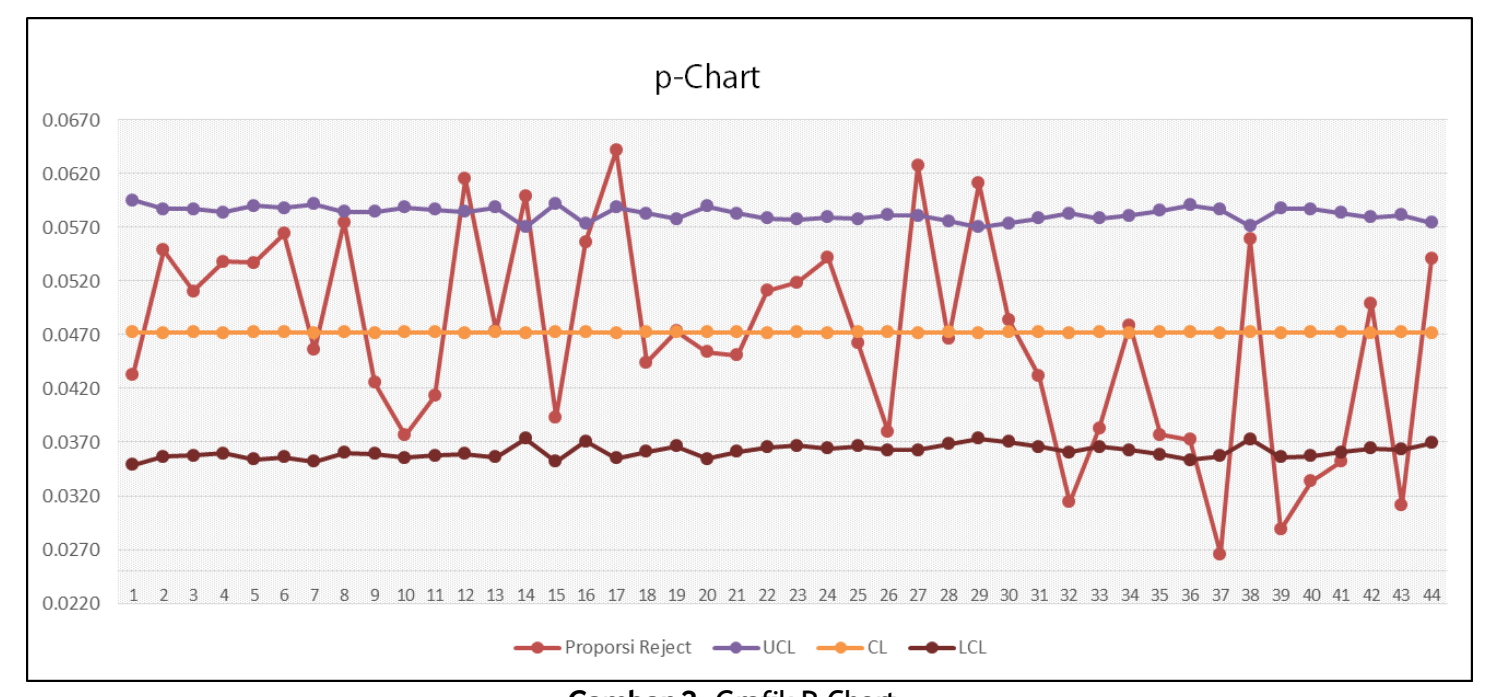

Gambar 2. Grafik P-Chart

Berdasarkan grafik diatas, dapat dikatakan bahwa proses produksi selama bulan September-Oktober 2019 tidak terkendali (out of control) yang dibuktikan bahwa adanya beberapa beberapa sample yang berada di luar batas kendali, yaitu pada sampel ke-12, 14, 17, 27, 29, 32, 37, 39, 40, 41, dan 43. Karena proses tidak 
terkendali, maka diperlukan revisi peta kendali $\mathrm{p}$ dengan mengeluarkan data yang out of control tersebut hingga proses terkendali. Grafik peta kendali p yang telah direvisi disediakan pada gambar 3.

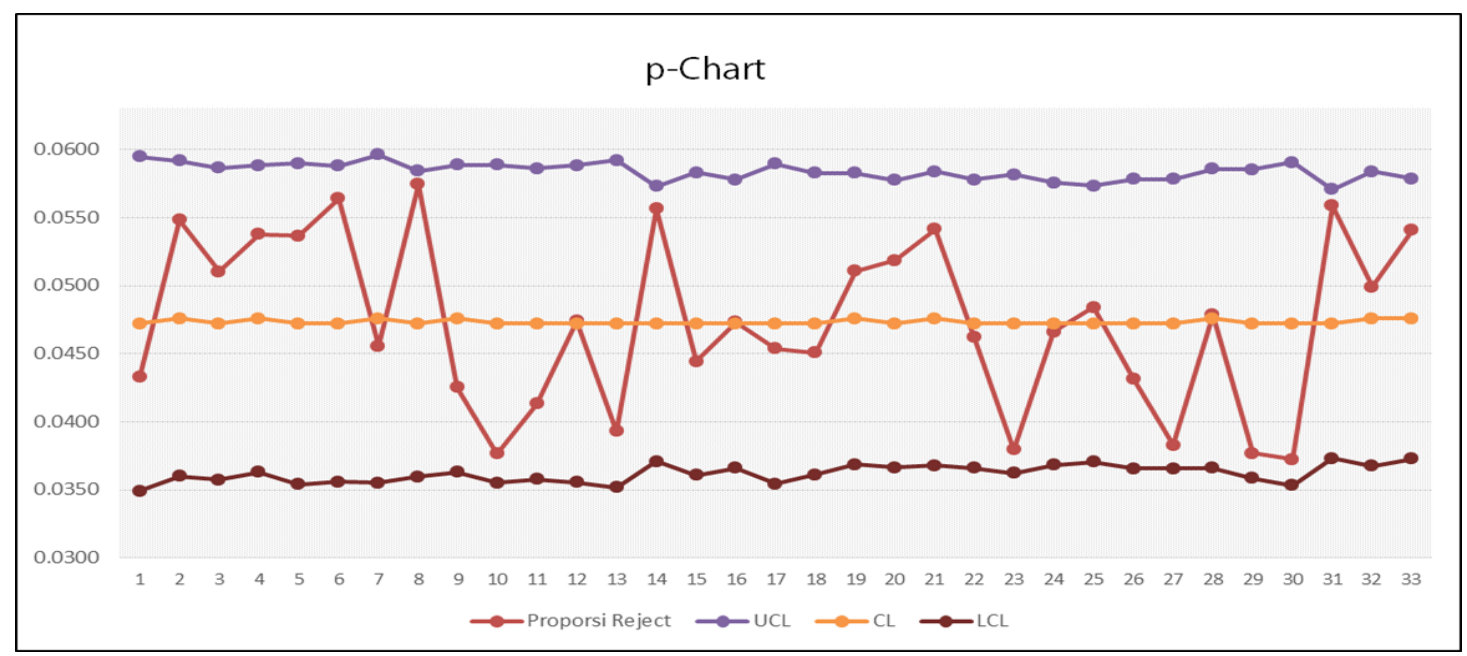

Gambar 3. Grafik P-Chart Revisi

Gambar 3 menjelaskan bahwa p-chart yang telah direvisi sudah stabil atau berada dalam batas kendali (incontrolled).

\subsubsection{Diagram Pareto}

Diagram pareto berfungsi untuk membandingkan persentase masing-masing jenis reject sehingga dapat menentukan reject tertinggi sebagai prioritas untuk dilakukan perbaikan (Mitra, 1993). Diagram pareto untuk jenis reject pada proses hexavalent chrome ditunjukkan pada Gambar 4 sebagai berikut.

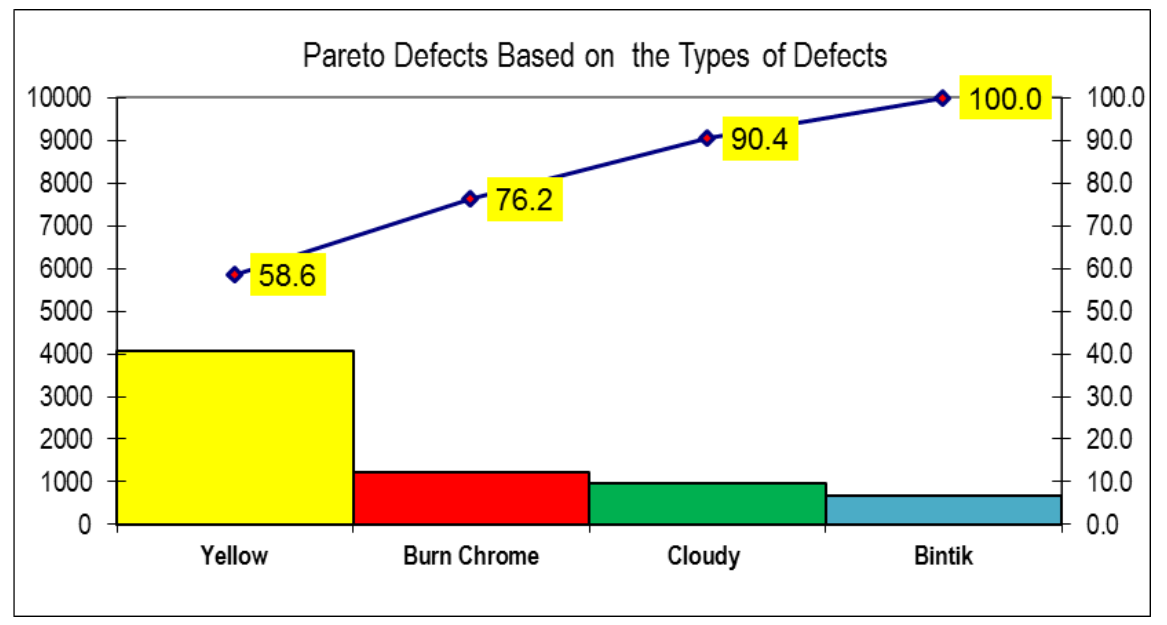

Gambar 4. Diagram Pareto

Berdasarkan diagram pareto diatas, jenis reject yang paling sering terjadi adalah yellow dengan jumlah reject 4.053 pcs atau dengan persentase sebesar $58,64 \%$, maka permasalahan difokuskan pada yellow reject dikarenakan tingkat reject tertinggi dan juga dilatar belakangi dengan historis perusahaan yang sebelumnya yellow reject belum pernah terjadi.

\subsubsection{DPMO dan Level Sigma}

Selanjutnya adalah menghitung DPMO setelah persentase reject didapat. Tujuan menghitung DPMO adalah untuk memperkirakan jumlah cacat atau reject yang terjadi jika perusahaan memproduksi sebanyak satu juta produk. 


$$
\text { DPMO }=\frac{1.000 .000 X \text { Jumlah Cacat }}{\text { Jumlah Unit X Jumlah Peluang Cacat Per Unit }}
$$

\begin{tabular}{|lc|}
\hline Jumlah Reject & 5.212 \\
Jumlah Unit & 109.527 \\
Jumlah Peluang Reject Per Unit & 4 \\
\hline \hline DPMO & $11.896,61$ \\
Level Sigma & 3,76 \\
\hline
\end{tabular}

Gambar 5. Perhitungan Level Sigma

Gambar 5 menunjukkan level sigma dari kondisi yang ada pada proses hexavalent chrome dengan menggunakan kalkulator sigma di Ms. Excel. Berdasarkan gambar 5, karena level sigma kondisi saat ini adalah 3.76, yang rendah dibandingkan dengan level sigma yang ideal yaitu enam. Maka, dapat disimpulkan bahwa proses hexavalent chrome perlu ditingkatkan dan dilakukan perbaikan.

\subsection{Analyze}

\subsubsection{Why Why Analysis}

Setelah masalah teridentifikasi dan data didapatkan, penelitian dilanjutkan dengan mencari penyebab permasalahan sampai ke akarnya dengan why why analysis. Why why analysis untuk yellow reject disediakan pada Tabel 2.

Tabel 2. Why Why Analysis

\begin{tabular}{|l|l|l|l|l|}
\hline \multicolumn{1}{|c|}{$\begin{array}{c}\text { Problem } \\
\text { Identification }\end{array}$} & \multicolumn{1}{|c|}{ Why 1 } & \multicolumn{1}{|c|}{ Why 2 } & \multicolumn{1}{c|}{ Why 3 } & Root Cause \\
\hline $\begin{array}{l}\text { Terdapat } \\
\text { kontaminasi } \\
\text { larutan nickel } \\
\text { pada larutan } \\
\text { chrome }\end{array}$ & $\begin{array}{l}\text { Proses rinsing } \\
\text { yang kurang } \\
\text { bersih setelah } \\
\text { pelapisan nickel }\end{array}$ & $\begin{array}{l}\text { Air bilasan (rinsing } \\
\text { water) kotor }\end{array}$ & $\begin{array}{l}\text { Tidak mengganti } \\
\text { rinsing water }\end{array}$ & $\begin{array}{l}\text { Tidak mengganti } \\
\text { rinsing water }\end{array}$ \\
\hline $\begin{array}{l}\text { Aliran arus } \\
\text { terhambat }\end{array}$ & $\begin{array}{l}\text { Kontaminasi } \\
\text { kawat jig yang } \\
\text { berkarat }\end{array}$ & $\begin{array}{l}\text { Compound jig } \\
\text { mengelupas }\end{array}$ & $\begin{array}{l}\text { Jig sudah lebih } \\
\text { dari life time }\end{array}$ & $\begin{array}{l}\text { Jig sudah lebih } \\
\text { dari life time }\end{array}$ \\
\hline $\begin{array}{l}\text { Adanya } \\
\text { kontaminasi } \\
\text { organik }\end{array}$ & $\begin{array}{l}\text { Additive yang } \\
\text { dipakai rusak }\end{array}$ & $\begin{array}{l}\text { Adanya barang } \\
\text { proses yang jatuh } \\
\text { atau tertinggal lama }\end{array}$ & $\begin{array}{l}\text { Tidak adanya } \\
\text { proses pencucian } \\
\text { tanki }\end{array}$ & $\begin{array}{l}\text { Tidak adanya } \\
\text { proses pencucian } \\
\text { tanki }\end{array}$ \\
\hline $\begin{array}{l}\text { Kenaikan suhu } \\
\text { yang melebihi } \\
\text { standard } \\
\text { (mencapai }>\text { 40 }\end{array}$ & $\begin{array}{l}\text { Saluran air chiller } \\
\text { bermasalah }\end{array}$ & $\begin{array}{l}\text { Adanya endapan } \\
\text { atau kotoran yang } \\
\text { menyumbat pada } \\
\text { pipa (strainer) }\end{array}$ & $\begin{array}{l}\text { Kurang kontrol } \\
\text { pada saluran } \\
\text { chiller }\end{array}$ & $\begin{array}{l}\text { Kurang kontrol } \\
\text { pada saluran } \\
\text { chiller }\end{array}$ \\
\hline $\begin{array}{l}\text { Filter kotor atau } \\
\text { tersumbat }\end{array}$ & $\begin{array}{l}\text { Filter paper tidak } \\
\text { menyaring dengan } \\
\text { maksimal }\end{array}$ & $\begin{array}{l}\text { Kurang } \\
\text { memperhatikan } \\
\text { filter }\end{array}$ & $\begin{array}{l}\text { Pencucian filter } \\
\text { paper hanya 2 } \\
\text { minggu sekali }\end{array}$ & $\begin{array}{l}\text { Pencucian filter } \\
\text { paper hanya 2 } \\
\text { minggu sekali }\end{array}$ \\
\hline $\begin{array}{l}\text { Output barang- } \\
\text { barang kekuning- } \\
\text { kuningan }\end{array}$ & $\begin{array}{l}\text { Rasio chromic } \\
\text { acid dan sulfat } \\
\text { tidak standard }\end{array}$ & $\begin{array}{l}\text { Kadar sulfat lebih } \\
\text { tinggi dibanding } \\
\text { chromic }\end{array}$ & $\begin{array}{l}\text { Tidak melakukan } \\
\text { analisa kadar } \\
\text { larutan yang } \\
\text { akurat }\end{array}$ & $\begin{array}{l}\text { Tidak melakukan } \\
\text { analisa kadar } \\
\text { larutan yang } \\
\text { akurat }\end{array}$ \\
\hline
\end{tabular}




\subsubsection{Fishbone Diagram}

Hubungan fishbone diagram dan why why analysis sangat erat, hasil why why analysis sebelumnya dapat dituangkan ke dalam fishbone diagram agar lebih mudah untuk dipahami dengan membaginya ke dalam empat faktor, yaitu man, material, machine, dan method yang ditunjukkan pada Gambar 6 .

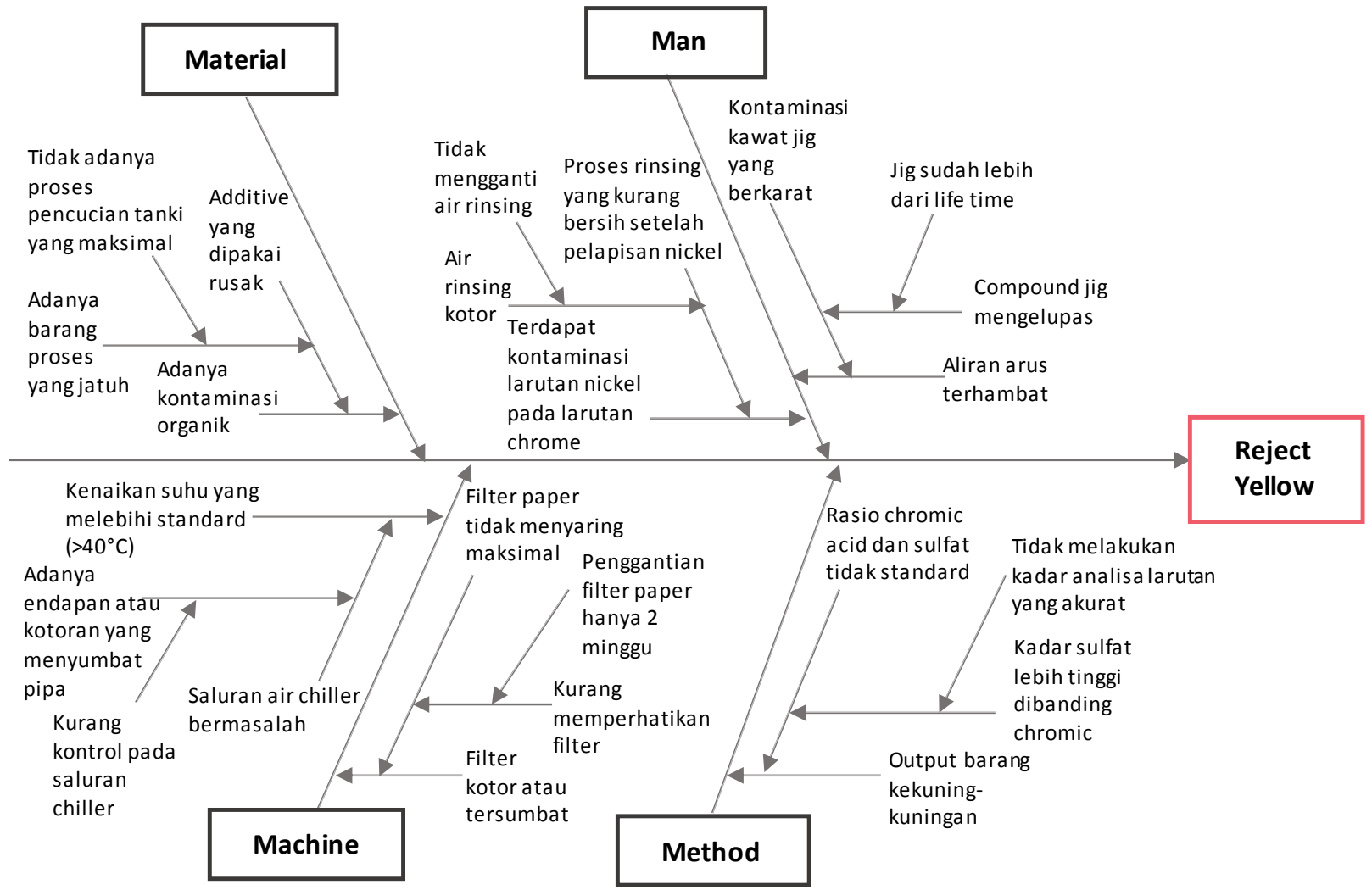

Gambar 6. Fishbone Diagram Yellow Reject

\subsection{Improve}

Berdasarkan hasil analisis dari why why analysis dan fishbone diagram pada tahap sebelumnya, terdapat beberapa akar penyebab yang menyebabkan yellow reject terjadi. Upaya pemecahan masalah tersebut, maka dibuat rencana perbaikan untuk menurunkan yellow reject pada proses hexavalent chrome tersebut disajikan pada Tabel 3 sebagai berikut.

\subsection{Control}

Alat umum yang digunakan untuk mengontrol proses perbaikan yang dilakukan terus menerus agar tetap terjaga adalah lembar kontrol dan evaluasi pekerjaan. Selain itu, dalam tahap ini pun dilakukan perbandingan hasil dari persentase reject, control chart, DPMO, dan level sigma sebelum perbaikan dan setelah perbaikan yang diimplementasikan untuk menentukan apakah perbaikan berhasil atau tidak. 
Tabel 3. Rencana Perbaikan Yellow Reject

\begin{tabular}{|c|c|c|c|}
\hline Kategori & $\begin{array}{c}\text { Problem } \\
\text { Identification }\end{array}$ & Root Cause & Rencana Perbaikan \\
\hline \multirow[t]{2}{*}{ Man } & $\begin{array}{l}\text { Terdapat } \\
\text { kontaminasi } \\
\text { larutan nickel } \\
\text { pada larutan } \\
\text { chrome }\end{array}$ & $\begin{array}{l}\text { Tidak } \\
\text { mengganti air } \\
\text { bilasan } \\
\text { (rinsing } \\
\text { water) }\end{array}$ & $\begin{array}{l}\text { Mengganti rinsing water } \\
\text { setiap pagi sebelum proses } \\
\text { produksi berlangsung }\end{array}$ \\
\hline & $\begin{array}{l}\text { Aliran arus } \\
\text { terhambat }\end{array}$ & $\begin{array}{l}\text { Jig sudah lebih } \\
\text { dari life time }\end{array}$ & Membuat jig yang baru \\
\hline Material & $\begin{array}{l}\text { Adanya } \\
\text { kontaminasi } \\
\text { organik }\end{array}$ & $\begin{array}{l}\text { Tidak adanya } \\
\text { proses } \\
\text { pencucian tanki }\end{array}$ & Melakukan proses dummy \\
\hline Method & $\begin{array}{l}\text { Output barang } \\
\text { kekuning- } \\
\text { kuningan }\end{array}$ & $\begin{array}{l}\text { Tidak } \\
\text { melakukan } \\
\text { analisa kadar } \\
\text { larutan yang } \\
\text { akurat }\end{array}$ & $\begin{array}{l}\text { Melakukan analisa kadar } \\
\text { larutan dengan test hull cell }\end{array}$ \\
\hline \multirow{2}{*}{ Machine } & $\begin{array}{l}\text { Kenaikan suhu } \\
\text { yang mele bihi } \\
\text { standard } \\
(\text { mencapai }> \\
\left.40^{\circ} \mathrm{C}\right)\end{array}$ & $\begin{array}{l}\text { Kurang kontrol } \\
\text { pada saluran } \\
\text { chiller }\end{array}$ & $\begin{array}{l}\text { Rutin mengontrol saluran } \\
\text { chiller }\end{array}$ \\
\hline & $\begin{array}{l}\text { Filter kotor } \\
\text { atau ters umbat }\end{array}$ & $\begin{array}{l}\text { Pencucian filter } \\
\text { paper hanya } 2 \\
\text { minggu sekali }\end{array}$ & $\begin{array}{l}\text { Mengevaluasi pemakaian } \\
\text { filter paper }\end{array}$ \\
\hline
\end{tabular}

\subsubsection{Lembar Kontrol}

Lembar kontrol adalah suatu alat umum yang dapat digunakan untuk mengontrol dan mengendalikan proses. Lembar kontrol sangat diperlukan untuk menjaga kualitas proses produksi dalam keadaan baik. Lembar kontrol yang dapat digunakan untuk mengontrol proses hexavalent chrome dan proses lainnya ada dua, yaitu:

\section{Checklist Harian Mesin}

Checklist harian mesin berfungsi untuk mengontrol serta mengecek kondisi seluruh mesin apakah dalam keadaan baik atau tidak. Sebelum proses produksi dimulai, operator dapat mengisi form checklist harian mesin terlebih dahulu.

\section{Daily Report Analysis}

Daily report analysis merupakan lembar untuk mengontrol hasil dari setiap analisis larutan. Lembar ini berfungsi untuk mengetahui hasil analisis larutan dan dibandingkan dengan range larutan tersebut apakah sudah sesuai atau belum. 


\subsubsection{Evaluasi Pekerjaan}

Perusahaan harus mengevalauasi pekerjaan yang telah dilakukan oleh seluruh karyawan untuk melihat apakah perbaikan untuk menurunkan yellow reject pada proses hexavalent chrome sudah optimal. Evaluasi pekerjaan dilakukan dengan dua cara, yaitu :

\section{Morning Briefing}

Morning briefing merupakan pengarahan yang dilakukan pada pagi hari. Pengarahan dilakukan dua kali seminggu, setiap hari senin dan kamis. Pengarahan hari senin dilakukan untuk memberikan motivasi dan bimbingan, sedangkan pengarahan hari kamis dilakukan untuk membahas masalah yang ditemukan serta menemukan solusinya.

2. Ulasan Pekerjaan (Job Review)

Ulasan pekerjaan bertujuan untuk membahas masalah yang telah dihadapi dalam satu minggu dan membuat rencana untuk minggu berikutnya agar seluruh pekerjaan terkontrol dan tidak kelolosan sehingga kualitas produk yang dihasilkan pun baik.

\subsubsection{Hasil Setelah Perbaikan}

Perbaikan yang telah dilakukan selama hampir dua bulan, selanjutnya dilakukan rekapitulasi hasil proses produksi bulan November-Desember 2019. Rekapitulasi tersebut dapat dilihat pada Tabel 4 sebagai berikut.

Tabel 4. Rencana Perbaikan Yellow Reject

\begin{tabular}{|c|c|c|c|c|c|c|c|c|}
\hline \multirow{2}{*}{ No } & \multirow{2}{*}{ Bulan } & \multirow{2}{*}{$\begin{array}{c}\text { Jumlah } \\
\text { Produksi }\end{array}$} & \multirow{2}{*}{$\begin{array}{l}\text { Jumlah } \\
\text { Reject }\end{array}$} & \multicolumn{4}{|c|}{ Jenis Reject } & \multirow{2}{*}{$\begin{array}{c}\text { Persentase } \\
\text { Reject }\end{array}$} \\
\hline & & & & $\begin{array}{c}\text { Burn } \\
\text { Chrome }\end{array}$ & Yellow & Cloudy & Bintik & \\
\hline 1 & November & 85,910 & 2,042 & 578 & 672 & 476 & 316 & $2.38 \%$ \\
\hline 2 & Desember & 75,678 & 1,378 & 296 & 213 & 515 & 354 & $1.82 \%$ \\
\hline & Total & 161,588 & 3,420 & 874 & 885 & 991 & 670 & $\begin{array}{c}\text { Rata-rata }= \\
2.12 \%\end{array}$ \\
\hline \multicolumn{4}{|c|}{ Persentase reject setiap jenis cacat } & $0.54 \%$ & $0.55 \%$ & $0.61 \%$ & $0.41 \%$ & \\
\hline
\end{tabular}

Berdasarkan tabel 4, setelah perbaikan dilakukan memberikan hasil yang signifikan bahwa persentase yellow reject turun menjadi $0.55 \%$ yang berada dibawah batas yang diizinkan perusahaan sebesar $1.5 \%$. Begitu pun dengan rata-rata persentase reject secara keseluruhan turun menjadi $2.12 \%$ berada dibawah toleransi perusahaan sebesar $3 \%$. Maka, dapat dinyatakan bahwa perbaikan yang dilakukan sangat berpengaruh dan memberikan hasil yang baik.

Setelah mengetahui hasil rekapitulasi, dilakukan pengukuran kembali untuk mengetahui kondisi proses setelah perbaikan apakah terkendali dengan menggunakan $p$-chart. Grafik p-chart hasil setelah perbaikan disajikan pada Gambar 7.

Gambar 7 menggambarkan bahwa proses tidak terkendali (out of control) karena adanya pola run (run pattern) pada 11 titik. Kesebelas titik tersebut berada di sisi yang sama yang dapat dilihat pada data yang sudah dilingkarkan dari gambar 7 di atas. Karena proses belum terkendali, maka peta kendali harus direvisi sampai terkendali dengan mengeluarkan kesebelas data tersebut. Hasil $p$-chart yang telah direvisi disediakan pada Gambar 8. 


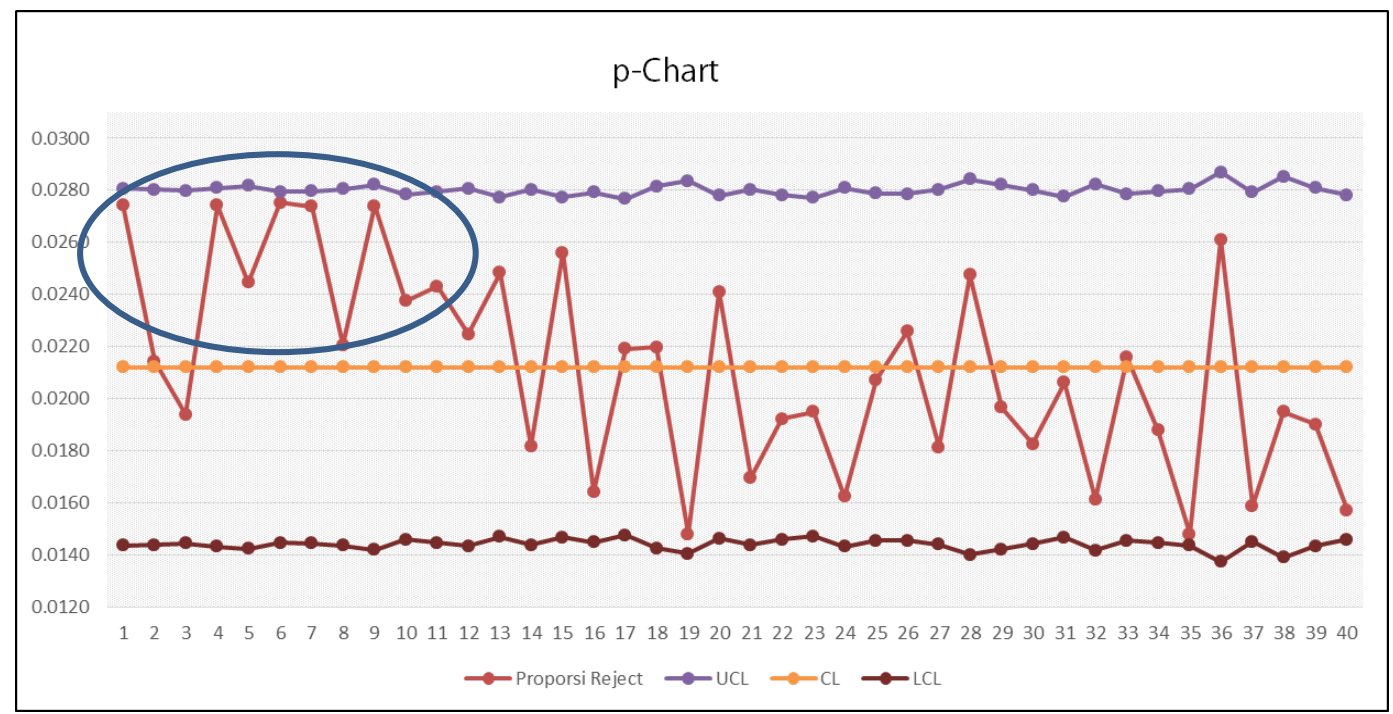

Gambar 7. Grafik P-Chart Setelah Perbaikan

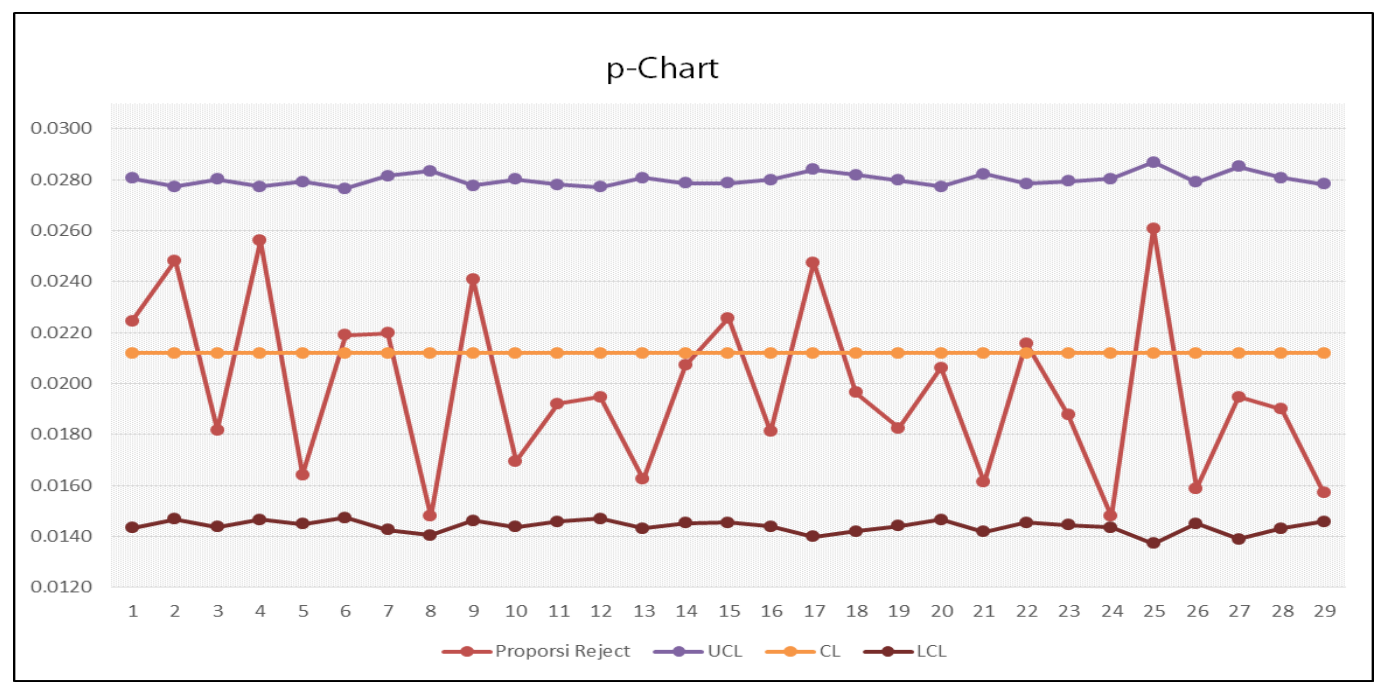

Gambar 8. Grafik P-Chart Setelah Perbaikan

Gambar 8 menjelaskan bahwa hasil peta kendali p setelah perbaikan yang telah direvisi sudah tidak ada yang membentuk pola dan berada dalam batas kendali (in-controlled), maka hasil proses tekendali tersebut akan digunakan untuk perhitungan untuk DPMO dan level sigma.

$$
\begin{aligned}
& \text { DPMO }=\frac{1.000 .000 \times \text { Jumlah Cacat }}{\text { Jumlah Unit } \times \text { Peluang Cacat Per Unit }} \\
& \text { DPMO }=\frac{1.000 .000 \times 2.326}{117.381 \times 4} \\
& \text { DPMO }=4.953,95
\end{aligned}
$$

Berdasarkan nilai DPMO yang telah didapat, kemudian dikonversikan ke level sigma dengan menggunakan Ms.Excel dan didapatkan level sigma sebesar 4,08. Data persentase yellow reject, nilai DPMO, dan level sigma setelah perbaikan sudah didapat, maka dibuatkan tabel sebelum dan setelah perbaikan dari ketiga data tersebut yang disajikan pada Tabel 5. 
Tabel 5. Rencana Perbaikan Yellow Reject

\begin{tabular}{|c|c|c|}
\hline & $\begin{array}{c}\text { Sebelum } \\
\text { Perbaikan }\end{array}$ & $\begin{array}{c}\text { Setelah } \\
\text { Perbaikan }\end{array}$ \\
\hline DPMO & $11.896,61$ & $4.953,95$ \\
\hline Level Sigma & 3,76 & 4,08 \\
\hline $\begin{array}{c}\text { Persentase } \\
\text { Yellow Reject }\end{array}$ & $2,77 \%$ & $0,55 \%$ \\
\hline
\end{tabular}

Tabel 5 menunjukkan bahwa hasil setelah perbaikan terjadi penurunan DPMO, peningkatan level sigma, dan penurunan persentase yellow reject. DPMO mengalami penurunan atau lebih rendah dari 11.896,61 menjadi 4.953,95 menyatakan bahwa dalam sejuta peluang memiliki kemungkinan reject yang terjadi lebih rendah dibandingkan sebelumnya. Level sigma yang meningkat dari 3,76 menjadi 4,08 menyatakan bahwa kemampuan proses produksi semakin baik. Persentase yellow reject mengalami penurunan dari 2,77\% menjadi $0,55 \%$ menyatakan bahwa penurunan yellow reject sangat signifikan dan sudah melebihi target penelitian untuk menurunkan yellow reject tersebut menjadi 1\%, serta persentase tersebut sudah masuk dalam batas toleransi perusahaan untuk setiap jenis reject sebesar $1,5 \%$.

\section{Kesimpulan}

Perbaikan yang dilakukan dengan menggunakan pendekatan DMAIC untuk menurunkan tingkat yellow reject pada proses hexavalent chrome plating plastik dinyatakan berhasil karena telah menurunkan dari persentase sebesar $2.77 \%$ menjadi $0.55 \%$. Perbaikan tersebut dengan melakukan analisis kadar larutan dengan test hull cell, melakukan proses dummy, membuat jig baru, rutin mengontrol saluran chiller, mengevaluasi pemakaian filter paper dan mengganti air bilasan (rinsing water) setiap hari.

\section{References}

1. Antony, N. (2011). Sistem Pengendalian Manajemen, Tangerang: Karisma Publishing Group.

2. Crosby, Philip B. (1979). Quality is Free: The Art of Making Quality Certain, New York: New American Library.

3. Evans, J. R. dan Lindsay, W. M. (2005). An In-troduction to Six Sigma\&Process Improvement, Ohio: Thomson.

4. Hatani, La. (2007). Manajemen Pengendalian Mutu Produksi Roti Melalui Pendekatan Statistical Quality Control (SQC), Jurnal Ekonomi dan Manajemen Unhalu.

5. Juran, J.M. (1989). Quality by Design, New York: Free Press.

6. Kotler dan Armstrong. (2008). Prinsip-Prinsip Pemasaran, Jakarta: Erlangga.

7. Mitra, A. (1993). Fundamentals of Quality Control and Improvement, New York: Macmillan Pub. Co.

8. Pande dan L. Holpp. (2005). Berpikir Cepat Six Sigma, Yogyakarta: Andi Offset.

9. Pyzdek, T. dan Keller, P.A. (2010). The Six Sigma Handbook: A Complete Guide for Green Belts, Black Belts, and Managers at All Levels, 3rd ed., McGraw-Hill, New York. 
JIE, Vol. 5, No.1, April 2020: 25-36

\section{Lampiran}
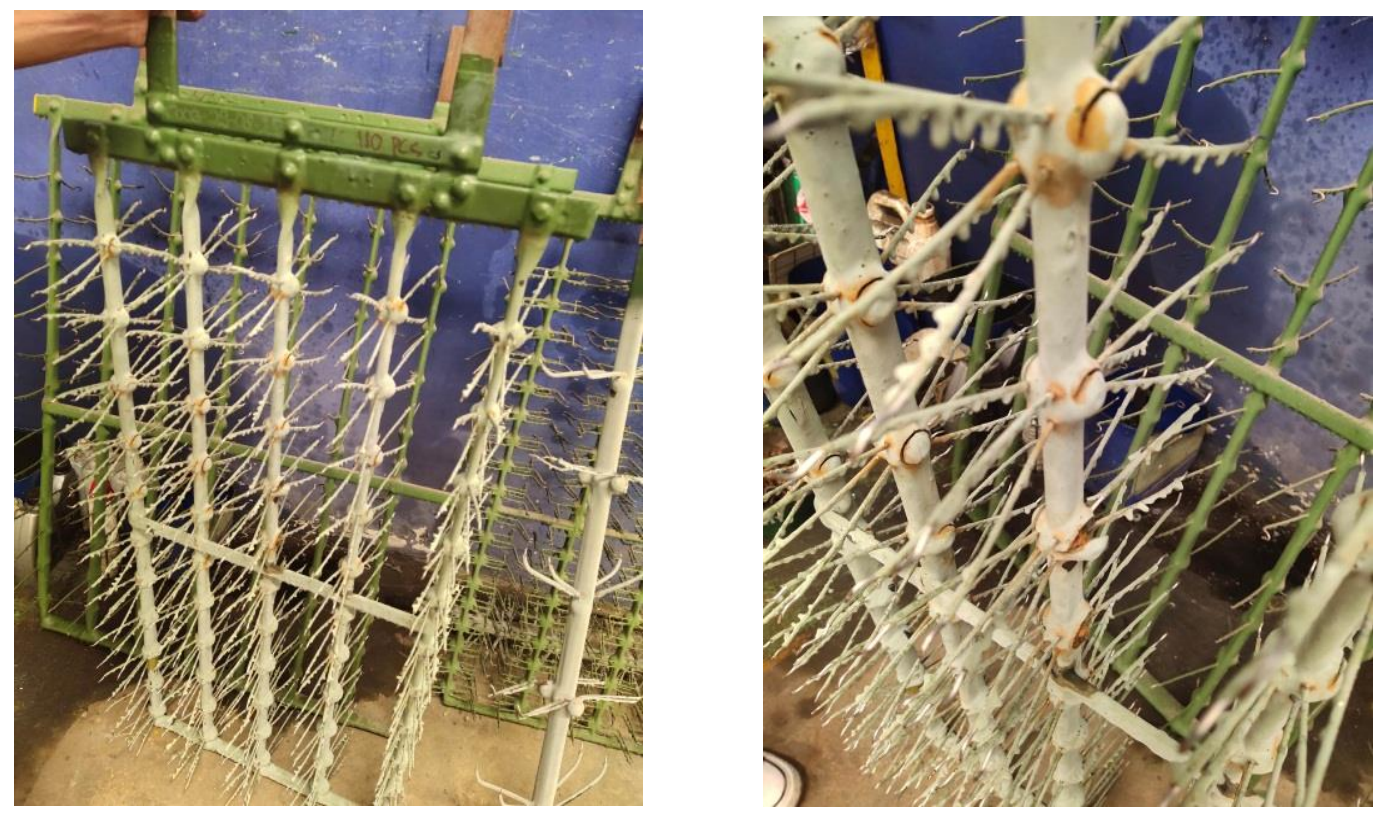

Gambar Keadaan Jig Lama (Jig Berkarat dan Mengelupas)
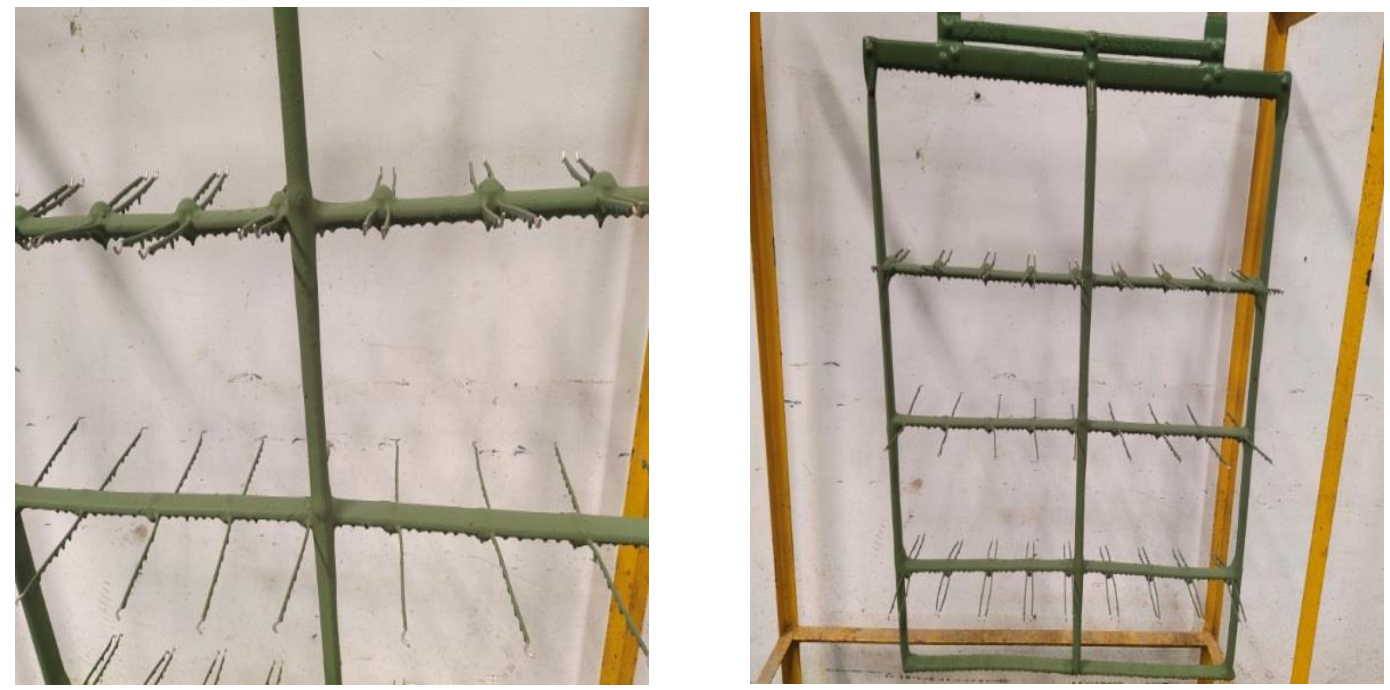

Gambar Penggantian Jig Baru 